\title{
RESEARCH
}

\section{A Comparative Transcription Map of the Murine Bare Patches (Bpa) and Striated (Str) Critical Regions and Human Xq28}

\author{
Michael L. Levin, Aurobindo Chatterjee, Antonella Pragliola, \\ Kim C. Worley, Manfred Wehnert, ${ }^{1}$ Olga Zhuchenko, \\ Randall F. Smith, ${ }^{2}$ Cheng Chi Lee, and Gail E. Herman ${ }^{3,4}$
}

Department of Molecular and Human Genetics, ${ }^{2}$ Department of Cell Biology, and ${ }^{3}$ Department of Pediatrics, Baylor College of Medicine, Houston, Texas 77030

The X-linked developmental mouse mutations bare patches ( $B p a)$ and striated (Str) may be homologous to human X-linked dominant chondrodysplasia punctata (CDPX2) and incontinentia pigmenti (IP2), respectively, based on their genetic mapping and clinical phenotypes. Bpa and Str have been localized to an overlapping critical region of $600 \mathrm{~kb}$ that demonstrates conserved gene order with loci in human Xq28 between DXS1104 and DXS52. As part of efforts to isolate the genes involved in these disorders, we have begun to develop a comparative transcription map spanning this region in both species. Using techniques of cross-species conservation and hybridization, exon trapping, and cDNA selection we have identified four known genes or members of gene families-caltractin, a member of the $\gamma$-aminobutyric acid $\left(G A B A_{A}\right)$ receptor gene family, a member of the melanoma antigen gene (MAGE) family, and several members of the murine-specific, X-linked lymphocyte regulated gene (XIr3) family. Trapped exons and, in some cases, longer cDNAs have been isolated for potentially 7-9 additional genes. One cDNA demonstrates highly significant homology with members of the Krüppel family of zinc finger transcription factors. A second novel cDNA demonstrates homology at the $3^{\prime}$ end of the predicted amino acid sequence to a LIM domain consensus. Gene order appears conserved among those cDNAs determined to be present in both human and mouse. Three of the murine transcripts appear to be present in multiple copies within the $\mathrm{Bpa} / \mathrm{Str}$ critical region and could be associated with a predisposition to genomic rearrangements. Reverse trancriptase PCR (RT-PCR) and Northern analyses demonstrate that several of the transcripts are expressed in mid-gestation murine embryos and neonatal skin, making them candidates for the Bpa and Str mutations and their respective homologous human disorders.

An interesting group of disorders are those involving the $\mathrm{X}$ chromosome, which demonstrate prenatal lethality in affected hemizygous males (for review, see Wettke-Schaefer and Kantner 1983; Davisson 1987). This lethality suggests that the involved genes have important roles in mammalian embryonic and/or fetal development. None of the genes involved in an X-linked dominant, male lethal disorder has been isolated, although at least four exclusively male lethal Xlinked disorders have been described in human and mouse (Happle 1987; Herman et al. 1996; Nelson et al. 1996). Based on the similarity of the

\footnotetext{
'Present address: Ernst-Moritz Arndt Laboratory, Institute for Human Genetics, D-17487 Greifswald, Germany.

${ }^{4}$ Corresponding author.

E-MAIL gherman@bcm.tmc.edu; FAX (713) 798-5386.
}

clinical phenotypes and/or the mapping of the loci within conserved $X$ chromosomal segments, it has been proposed by us (Angel et al. 1993) and others (Happle 1979; Happle et al. 1983; Davisson 1987) that some of these disorders may represent mutations in homologous genes.

Our research has focused on the isolation of the genes involved in the murine, male lethal bare patches (Bpa) and striated (Str) mutations that may be homologous to human X-linked dominant chondrodysplasia punctata (CDPX2) (McKusick no. 302960) and incontinentia pigmenti (IP2) (McKusick no. 308310), respectively. The original Bpa and Str mutations arose in female offspring of males who had received multiple doses of X-irradiation (Phillips 1963; Phillips et al. 1973). Heterozygous Bpa females are af- 


\section{LEVIN ET AL.}

fected with a skeletal dysplasia and often have asymmetric cataracts that may be associated with microphthalmia. There is a characteristic progression of skin abnormalities that includes a patchy hyperkeratotic skin eruption on postnatal day $5-7$. These plaques quickly resolve, leaving "bare patches" arranged in a horizontal, striped pattern over the skin. The asymmetry and patterning of the physical findings and the variability in the phenotype are presumed to result from random X-inactivation. There is reduced viability among affected females with both pre- and early postnatal losses; affected males are reported to die shortly after implantation (Phillips et al. 1973). Str females are normal in size and develop striations of their coat between postnatal day 1214. Affected male embryos and $\sim 40 \%$ of affected females die in midgestation between day 11-13 post coitum (pc) (G. Herman, unpubl.).

We have mapped the Bpa and Str mutations to an overlapping $600-\mathrm{kb}$ interval on the mouse $\mathrm{X}$ chromosome between the loci DXHXS1104 and DXHXS52, which are detected by anonymous, conserved human genomic probes from Xq28 (Herman et al. 1991a; Angel et al. 1993). Subsequently, a complete physical yeast artificial chromosome (YAC) contig was developed spanning the $\mathrm{Bpa} /$ Str critical region (Chatterjee et al. 1994). YAC and cosmid contigs for the equivalent region in human Xq28 have also been constructed (Palmieri et al. 1994; Rogner et al. 1994). Gene order is conserved across the region for all genes studied, with the exception of the locus F8a (F8A). A single copy of this gene exists in the mouse, whereas three copies that lie $\sim 3-4 \mathrm{Mb}$ telomeric are found in human Xq28 (Levinson et al. 1990; Faust et al. 1992).

In 1979, Happle proposed that the Bpa mutation was homologous to human CDPX2 based on the striking similarities in the clinical features of both disorders (Happle 1979), although exclusion mapping and linkage analysis in three small CDPX2 families do not support this homology (Traupe et al. 1992). We subsequently proposed that Str is homologous to human IP2 based on their common mode of inheritance and their respective mapping to conserved segments of the $\mathrm{X}$ chromosome (Sefiani et al. 1989; Angel et al. 1993; Smahi et al. 1994). It should be noted, however, that Str females do not demonstrate the progressive skin findings so characteristic of human IP2 (for review, see Landy and Donnai 1993). It is also possible that $B p a$ and Str are allelic and represent mutations in a single gene, al- though no overlap in the phenotypes has been detected (G. Herman, unpubl.). Other possible explanations for the mapping of the two mutations to the same small region have been discussed (Angel et al. 1993).

As a first step toward the isolation of the genes involved in these mutations, we describe here the construction of a partial transcription map for the $B p a / S t r$ critical region and the homologous interval in Xq28. Some of the genes and partial cDNAs isolated appear to be excellent candidates for the murine mutations and their human counterparts.

\section{RESULTS}

\section{Cosmid Contig Construction}

To facilitate the isolation of genes in the murine and human $\mathrm{Bpa} / \mathrm{Str}$ critical regions, cosmids were assembled between DXS1104 (DXHXS1104) and DXS52 (DXHXS52) in both species. In the mouse, five YACs from our existing contig (C73E6, B16S5, C131B2, B20S1, and D35D6) were subcloned into cosmids using the Supercos vector (see Methods). Three independent P1 clones were also isolated at DXBay 18 and DXBay20. Two hundred forty cosmids containing mouse DNA inserts were assembled into contigs by comparing EcoRI, BamHI, and rare-cutter restriction enzyme digestion patterns, by PCR and Southern analysis using DNA markers from the region, and by hybridization with selected whole cosmids or fragments from them (see Fig. 1A). There are two gaps in the contig. The gap distal to DXHXS1104 contains few markers with which to order the cosmids, and, as discussed below, this gap appears to be covered by human cosmids. A second gap within the YAC D35D6 is probably less than 50 $\mathrm{kb}$ and may also be spanned by human cosmids.

Human cosmids were isolated by hybridization of the individual YACs CA02519, CB12458, yWXD526, and P131 to filters containing cosmids prepared from flow-sorted human $X$ chromosomes at Lawrence Livermore National Laboratories (LLNL). For better coverage near DXS1104, the YAC CA02519 was also subcloned into Supercos, and several LLNL cosmids were isolated that hybridized with DXS1104. The human cosmids were placed into bins (Wapenaar et al. 1994) defined by hybridization with overlapping YACs, genomic probes, and cDNAs (see Fig. 1B) and several small contigs have been assembled (data not shown). 
A

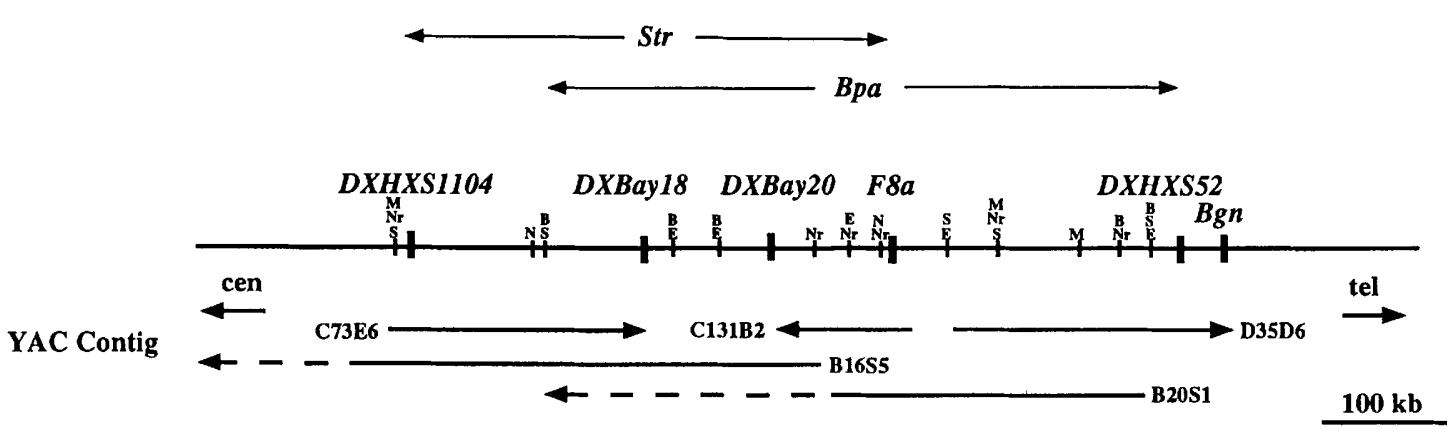

Cosmid Contig

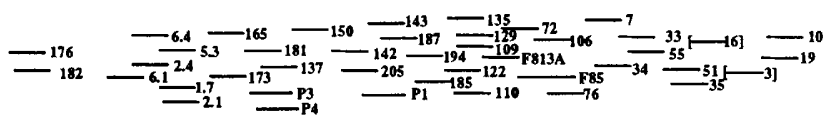

Exons

cDNAs

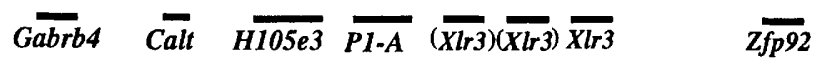

B

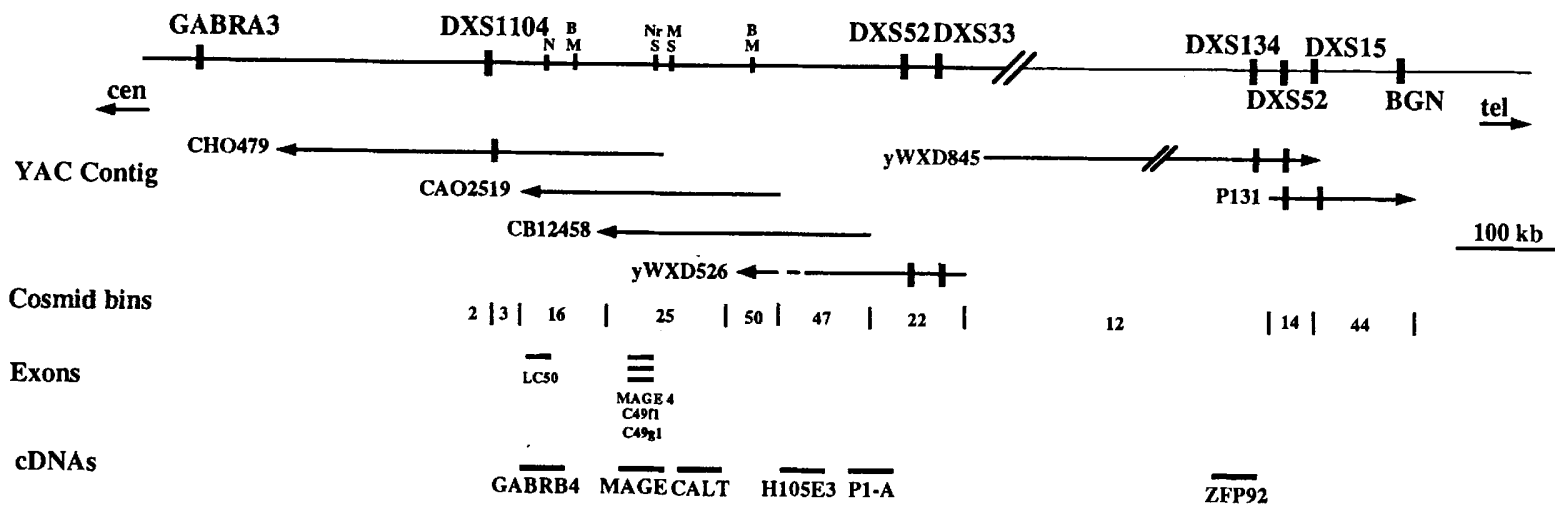

Figure 1 Physical contigs of the murine $(A)$ and human $(B) B p a$ and Str critical regions. (Dashed lines) Chimeric regions; (solid lines) X-specific regions of YACs. (Arrowheads) Right ends of YACs. Selected rare-cutter restriction sites are shown (small vertical bars): (B) BssHII; (E) Eagl; (M) Mlul; (N) Notl; (Nr) Nrul; and (S) Sadl. Selected loci are shown above the genomic maps and are indicated by large vertical bars. More complete descriptions of the murine (Chatterjee et al. 1994) and human (Palmieri et al. 1994; Rogner et al. 1994) contigs have been published. The murine cosmid contigs were assembled as described in the text. Only a subset of cosmids spanning the region are shown. Brackets around cosmids 16 and 3 indicate that their precise position and whether they overlap with nearby cosmids is uncertain. For the human cosmids, the numbers of cosmids within each bin are given. Individual coordinates for LLNL cosmids may be obtained from the authors. For exons listed together, the relative order of the sequences is not known. Physical distances are drawn approximately to scale with the exception of the sizes of exons and CDNAs. The double slash in the human contig indicates that the exact physical distance is not known, and a small gap exists between the YACs yWXD526 and yWXD845. The approximate location of each CDNA was determined by Southern hybridization of the clone to YACs and selected cosmids listed in Fig. 1. The position of the MAGE CDNA was assigned solely on the basis of the trapped exon and mapping performed by Rogner et al. (1995). 


\section{LEVIN ET AL.}

Rare-cutter restriction enzyme digests were performed on selected cosmids to detect CpG islands and provide a minimum estimate for the number of genes in the region. Our previous genomic (Faust and Herman 1991; Faust et al. 1992) and YAC (Chatterjee et al. 1994) pulsed-field gel (PFG) restriction maps helped to anchor the $\mathrm{mu}-$ rine cosmid maps, although additional rarecutter sites and $\mathrm{CpG}$ islands were encountered (see Fig. 1). It appears that there are 10 or more $\mathrm{CpG}$ islands in the $600-\mathrm{kb}$ region between $D X$ HXS1104 and DXHXS52. A more limited search for $\mathrm{CpG}$ islands in $\mathrm{Xq} 28$ was restricted to the cosmids subcloned from the YAC CA02519, and three islands were detected. The NotI site in the YAC CA02519 lies $\sim 50 \mathrm{~kb}$ proximal to the BssHII and MluI sites and is not associated with additional rare-cutter restriction enzyme sites.

\section{Exon Isolation and Characterization}

Exon trapping was performed with 14 mouse cosmids, three human cosmids, and one P1 clone. The murine clones were chosen based on their location within the contig or the presence of a $\mathrm{CpG}$ island and/or evolutionarily conserved sequences within the clone. The latter were demonstrated by probing digested cosmids with radiolabeled first-strand cDNA prepared from newborn pig brain or cultured skin fibroblast mRNA (so-called reverse Northerns) (deGouyon et al. 1996). The three human cosmids contained CpG islands and mapped to the region of the proximal gap in the murine contig.

A total of 31 independent murine and human putative exon fragments have been isolated to date (see Table 1). Approximately $15 \%$ of the sequenced fragments were vector-derived HIV or Escherichia coli sequences. To help select among the numerous exons and potential genes those that might be likely candidates for Bpa and Str, expression patterns were determined for many of the murine exons using reverse transcriptase PCR (RT-PCR). Exons from the P1 clone and from cosmid 10 demonstrated the highest level of expression in newborn skin (data not shown), whereas those from cosmid 33 and 16/135 were widely or ubiquitously expressed, respectively. Therefore, we were unable to exclude many of the potential candidate genes from consideration.

All of the sequenced exon fragments were analyzed for protein and DNA homologies using the National Center for Biotechnology Information (NCBI) BLAST email server. Several exon se- quences were identical to those of known genes. These included a human exon from a melanoma antigen gene (MAGE) family member and two exons from a murine cosmid that demonstrated identity or near-identity with sequence from the Xlr3 subfamily of X-linked, murine-specific lymphocyte-regulated genes. Independent mapping of human MAGE family members within Xq28 (Rogner et al. 1995) and of the two highly homologous murine genes $X l r 3 a$ and $X l r 3 b$ near $B g n$ on the mouse $X$ chromosome (Bergsagel et al. 1994), are consistent with our exon trapping data. A full-length $X \operatorname{lr} 3 b$ cDNA probe was obtained from Dr. Leif Bergsagel (National Cancer Institute, Bethesda, MD); it demonstrates a complex pattern of hybridization to the YACs B16S5, $\mathrm{B} 20 \mathrm{~S} 1, \mathrm{C} 131 \mathrm{~B} 2$, and D35D6 as well as to selected murine cosmids (data not shown). It is likely that these hybridizations are specific because there was no preassociation of the probe or filter, and identical clean signals were obtained on cloned DNAs and DNA from somatic cell hybrids containing the mouse $X$ chromosome. The hybridization results suggest that three copies of $X I r 3$ subfamily members are present in the region. Because of the high degree of sequence identity among family members, we have not determined the relative locations of $X l r 3 a$ or $X l r 3 b$ or whether the presumed third copy is expressed. The most likely locations for the three copies of the gene family are shown in Figure 1A.

Exons from several novel genes were also detected, some of which demonstrated significant homologies to known genes. These included two mouse exons from a cosmid at the distal limit of the contig that have high homology to the Drosophila Krüppel protein and other similar zincfinger transcription factors and a human exon with high homology to the family of $\gamma$-aminobutyric acid $\left(\mathrm{GABA}_{\mathrm{A}}\right)$ receptors. Longer cDNAs for both of these transcripts were isolated and are discussed below.

Finally, several exons derived from nonoverlapping cosmids subcloned from well-characterized YACs had identical or nearly identical sequences. An exon from cosmid 16 subcloned from the D35D6 YAC and an exon from cosmid 135 subcloned from the B20S1 YAC have identical 76-bp sequences. Analysis of the two cosmids using other markers confirm the distinct map locations shown in Figure 1. Sequences with near identity to those from exons in cosmid 33 have been found in trapped exons from cosmids 129 , 72 , and 110 . An example of a Southern hybrid- 


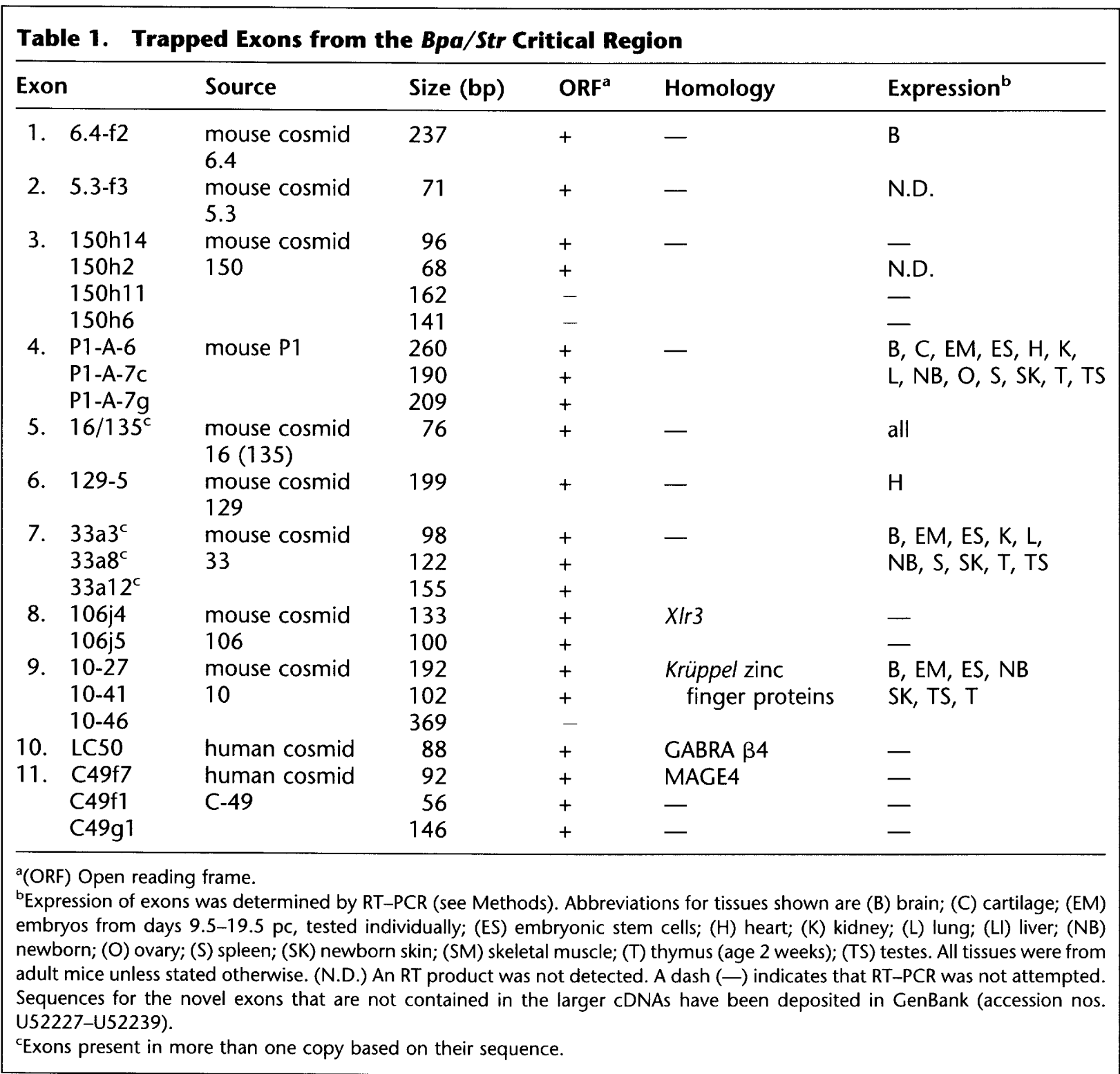

ization using exon $33 \mathrm{a} 3$ to confirm the sequence homology data is shown in Figure 2. It demonstrates the presence of three copies of the $33 \mathrm{a} 3$ sequence within the region, as well as a fourth copy (arrowhead) elsewhere on the mouse $X$ chromosome.

\section{CDNA Isolation and Characterization}

Longer cDNAs were isolated corresponding to three sets of trapped exons. Two of the cDNAs, $P 1-A$ and $Z f p 92$, were identified after hybridization of cDNA libraries. The third, GABRB4, was obtained using cDNA selection. These transcripts are discussed individually below. In addition, a novel, partial human cDNA (H105E3) was isolated independently using a reciprocal hybridization approach (Lee et al. 1995). The mapping of a human cDNA for caltractin (CALT) to this interval has already been described (Chatterjee et al. 1995). Its position and comparative map locations for the other transcripts are shown in Figure 1.

\section{GABRB4}

A human exon of $88 \mathrm{bp}$ was trapped from a cosmid (LC50) containing a NotI site located $\sim 60 \mathrm{~kb}$ 


\section{LEVIN ET AL.}

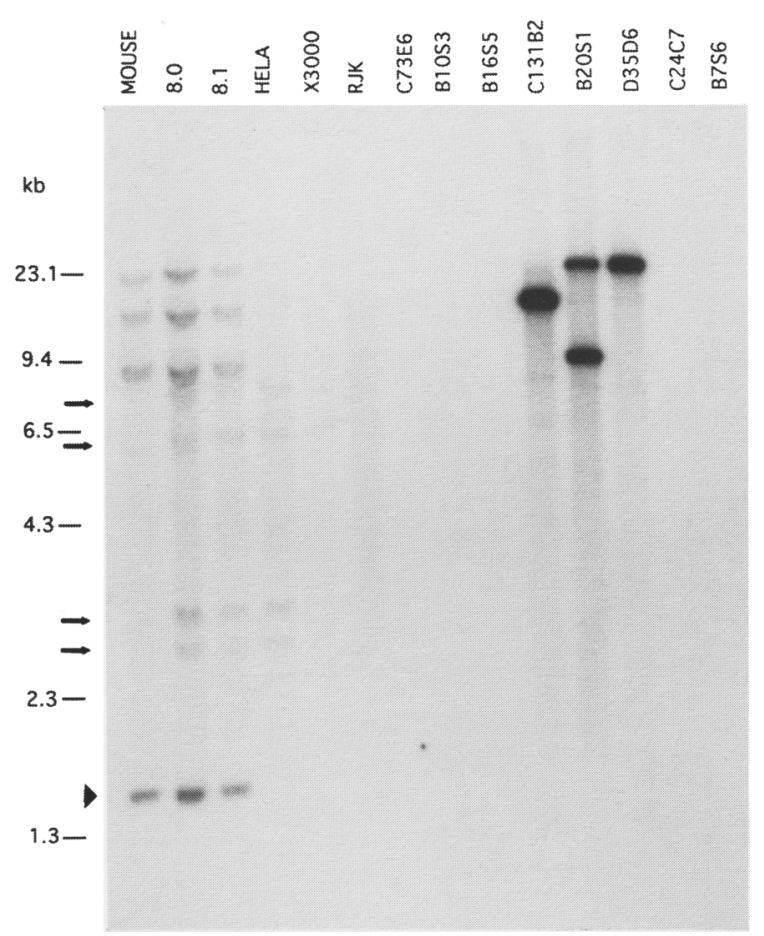

Figure 2 Southern blot hybridization of the 98-bp exon fragment $33 \mathrm{a} 3$ to DNA from selected murine YACs and cell lines. Clones 8.0 and 8.1 are somatic cell hybrids containing the mouse $\mathrm{X}$ chromosome in a human HeLa background (Herman et al. 1991b). $X 3000$ is a somatic cell hybrid containing human Xq24-Xq28 in a Chinese hamster background (Nelson et al. 1989). The cell lines HELA and RJK are the parental human and hamster controls, respectively. Southern blotting was performed as described (see Methods) and the film exposed overnight with an intensification screen at $-80^{\circ} \mathrm{C}$. The exon fragment produces three signals on the YACs C131B2, B20S1, and D35D6 in the Bpa/Str critical region and a fourth signal (arrowhead) elsewhere on the mouse $X$ chromosome. Arrows indicate human-specific bands.

distal to DXS1104 (see Table 1 and Fig. 1B). This exon demonstrated significant homology in the DNA and protein sequence to the aminoterminal-coding region of the family of $\beta$ subunits of the $\mathrm{GABA}_{\mathrm{A}}$ receptor gene family, the highest homology being to the chicken $\beta 4$ gene (Macdonald and Olsen 1994). Subsequently, a 240-bp partial human cDNA (cDNA2) was isolated using cDNA selection with the human YAC CA02519. It demonstrated homology to the $3^{\prime}$ end of the same $\mathrm{GABA}_{\mathrm{A}}$ receptors, suggesting that the trapped exon fragment and partial cDNA are part of the same transcript.

\section{HIO5E3}

The H105E3 cDNA was identified in an arrayed, human heart cDNA library (Lee et al. 1995) by hybridization with a LLNL cosmid that was also detected by the YAC CB12458. The 1215-bp partial cDNA hybridizes to a $1.5-\mathrm{kb}$ message on Northern blots and is expressed in all of the human tissues tested, which include brain, heart, liver, lung, kidney, skin, and placenta (data not shown). It contains an open reading frame (ORF) of 175 amino acids starting at base pair 499, which shows high homology to enzymes involved in cholesterol and steroid metabolism (see Table 2).

\section{Pl-A}

The clone P1A encodes a 2009-bp partial cDNA with an ORF of $1056 \mathrm{bp}$ and 352 amino acids (see Fig. 3). Expression studies using RT-PCR and Northerns show the highest levels of expression of P1-A in newborn skin, adult kidney, ovary, testis, and mid-gestation embryos (see Fig. 4), making it an excellent candidate for both Bpa and Str. BLAST analysis demonstrated no homology to known genes, but did identify a human expressed-sequence tag (EST) sequenced by the IMAGE Consortium (clone 129221). In an attempt to ascertain functional protein domains within P1-A, an enhanced search was performed using the BEAUTY program (Worley et al. 1995). A series of local alignments identified the families of $\mathrm{Cys}_{2} \mathrm{His}_{2}$ and LIM domain zinc-finger proteins (Sanchez-Garcia and Rabbitts 1994; Dawid et al. 1995). Closer inspection of $P 1-A$ indicated that it contains the single LIM domain motif Cys $\mathrm{X}_{2}$ Cys $_{19}$ His $_{2}$ Cys $_{2}$ Cys $_{2}$ Cys $_{19}$ CysX $_{2}$ Cys at its $3^{\prime}$ end between amino acids 292 and 347 of the predicted protein sequence, where $\mathrm{X}$ is any amino acid (see Fig. 3). The human EST 129221 was obtained, and it hybridizes to the human YACs CB12458 and yWXD526 as expected from the comparative physical maps. The entire human clone was resequenced; it contains an insert of $404 \mathrm{bp}$ that includes 123 amino acids from the 3 ' coding region of the human P1-A gene, a stop codon, and 32 bp of additional $3^{\prime}$ untranslated sequence. A comparison of the equivalent regions of the murine cDNA and human EST is shown in Figure 3B. The amino acid sequences share $81 \%$ identity. In the LIM domain, 52 of 56 amino acids are identical (93\%) and the four differences are conservative substitutions. 


\begin{tabular}{|c|c|c|c|c|c|}
\hline cDNA & Source & Size (bp) & Protein homology & $\begin{array}{l}\text { GenBank } \\
\text { accession No. }\end{array}$ & $\begin{array}{l}\text { Reference/method } \\
\text { of isolation }\end{array}$ \\
\hline 1. GABRB4 & human & $88+240^{a}$ & $\begin{array}{l}\text { chicken } \mathrm{GABA}_{\mathrm{A}} \beta 4 \\
(7.5 \text { e- } 9)\end{array}$ & U47334 & this work-cDNA selection \\
\hline 2. Caltractin & human & N.D. & - & - & Chatterjee et al. (1995) \\
\hline 3. H105E3 & human & $\begin{array}{l}1215 \\
525 \text { ORF }\end{array}$ & $\begin{array}{l}\text { Nocardia NAD(P)- } \\
\text { dependent } \\
\text { cholesterol } \\
\text { dehydrogenase } \\
\text { (8.0 e-13) } \\
\text { Mesocricetus 3- } \beta \\
\text { hydroxysteroid } \\
\text { dehydrogenase } \\
(6.1 \text { e-4) }\end{array}$ & U47105 & $\begin{array}{l}\text { this work-arrayed } \\
\text { cDNA library probing }\end{array}$ \\
\hline 4. $P 1-A$ & mouse & $\begin{array}{l}2009 \\
1056 \text { ORF }\end{array}$ & $\begin{array}{l}\text { human EST clone } \\
129221 \text { ( } 1.5 \text { e- } 86, \\
\text { DNA homology) }\end{array}$ & U46687 & $\begin{array}{l}\text { this work-hybridization } \\
\text { screening of cDNA } \\
\text { libraries using } 463-b p \\
\text { exon-connected } \\
\text { fragment of } P 1-A-7 \mathrm{c} \\
\text { and } 7 \mathrm{~g}\end{array}$ \\
\hline 5. $x / r 3$ & mouse & ND & - & - & Bergsagel et al. (1995) \\
\hline 6. MAGE & human & ND & - & - & Rogner et al. (1995) \\
\hline 7. Zfp92 & mouse & $\begin{array}{l}2940 \\
1467 \text { ORF }\end{array}$ & $\begin{array}{l}\text { zinc finger protein } \\
\text { KOX4 (3.1 e-132) } \\
\text { rat zinc finger } \\
\text { transcription factor } \\
\text { Kid-1 (3.1 e-131) }\end{array}$ & U47104 & $\begin{array}{l}\text { this work-hybridization } \\
\text { screening of cDNA } \\
\text { library using exons } \\
10-27,10-41 \text {, and } 10-46\end{array}$ \\
\hline
\end{tabular}

Zfp92

A 3-kb cDNA containing sequences from the trapped products $10-27,10-41$, and $10-46$ was isolated from a 14.5-day mouse embryo library. This cDNA contains an ORF of $1467-b p$, which encodes a 489 -amino-acid protein (see Fig. 5). It has KRAB A and KRAB B boxes at its $5^{\prime}$ end and eight consecutive $\mathrm{C}_{2} \mathrm{H}_{2}$ zinc-finger motifs of the type Cys- $\mathrm{X}_{2}-$ Cys $-\mathrm{X}_{3}-$ Phe $-\mathrm{X}_{5}-$ Leu- $\mathrm{X}_{2}-$ His $-\mathrm{X}_{3}-$ His-Thr-Gly-Glu-Lys-Pro-Tyr/Phe- $X$, where $X$ can be any amino acid and variability from the consensus is found most often in the last seven amino acids (Aubry et al. 1992; Margolin et al. 1994). A single ninth finger is found in the protein sequence $45 \mathrm{bp} 3^{\prime}$ to the other eight fingers, and the seventh finger contains a tyrosine instead of a cysteine in the fourth position of the finger. This gene has been designated $Z f p 92$, as the next member of the large Krüppel gene subfamily of zinc-finger proteins (Bellefroid et al. 1989). Although expression of the exons 10-27 and $10-41$ has been demonstrated by RT-PCR in selected adult tissues, newborn skin, and murine embryos (see Table 1), no signals have been detected on Northern blots using the 3-kb cDNA. This fact may be related to the extremely low levels of expression of the transcript.

\section{DISCUSSION}

We have developed a partial transcription map for the $600-\mathrm{kb}$ region of the mouse $\mathrm{X}$ chromosome between DXHXS1104 and DXHXS52 as part of an effort to isolate the genes involved in the Bpa and Str mutations. Because of the almost absolute conservation of genes among mammalian $\mathrm{X}$ chromosomes, we have isolated exons and cDNAs from both human and mouse and performed comparative mapping of clones onto physical contigs in both species. Four conserved, novel partial cDNAs are reported here (GABRB4, H105E3, $P 1-A$, and $Z f p 92$ ) as well as one or more 


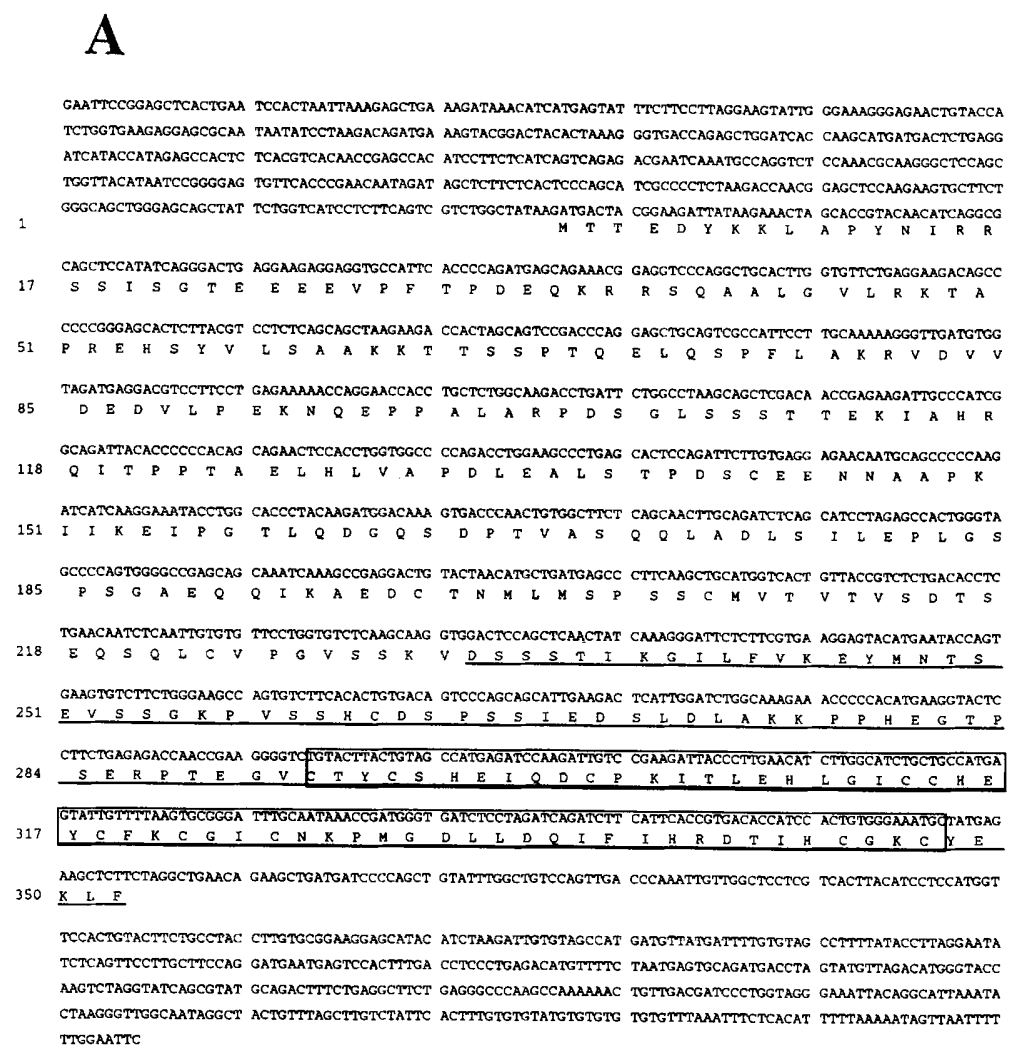

\section{B}

mouse $P 1-A$ human $\mathrm{P} 1-\mathrm{A}$ PSSSTIKGIL FVKEYMATSE YSSGKPVSSH CDSPSSIEDS LDLAKKPPHE DSSSTTKGL FVKEYNASE VSSGKPVSAR YSNVSSIEDS FAMEKKPPC

mouse P1-A

human P1-A

LIM consensus

mouse $P 1-A$

human P1-A

LIM consensus
DLLDQIFIHR DTIHCGKCYE KLF
IIIIIIII IIIIIIII IIII
DLLDQIFIHR DTIHCGKCYE KLF

GTP-SERPTE GVCTYCSHET QDCPKITLEH LGICCHEYCR KCGICNRPMG

329

STPYSERTTG GICTYCNREI RDCPKITLEH LGICCHEYCF KCGICSKPMG

.............. .
100

200

300

500

600

700

800

900

1000

1100

1200

1300

1400

1500

1600

1700

1900

2000

Figure 3 Sequence analysis of $P 1-A$. (A) Complete nucleotide and predicted amino acid sequence of the 2009-bp murine P1-A cDNA clone. Nucleotide positions are given to the right and amino acid positions to the left. The underscored amino acids are presented with the equivalent human sequence in $B$. The boxed amino acids comprise the putative LIM domain. Although no Kozak consensus sequence (Kozak 1989) was found at the initiator methionine, an in-frame stop codon was present 81 bases $5^{\prime}$ with no intervening methionine codons. No polyadenylation signal was found in the cDNA clone, and preliminary evidence suggests that alternative splicing within the coding region may occur (data not shown). (B) Comparative predicted amino acid sequences of $3^{\prime}$ coding region of murine $P 1-A$ and human EST 129221. The numbering corresponds to the amino acids shown in $A$. The human coding sequence is 123 amino acids, with a single base-pair insertion after amino acid 283 of the murine sequence. Vertical lines indicate identities and single dots represent conservative amino acid substitutions. A LIM domain consensus sequence showing the absolutely required cysteine and histidine residues is presented below the amino acid sequences.

members of species-specific gene families (human MAGE cDNAs and murine $X l r 3$ genes). We have also demonstrated that the region in the mouse is complex and contains several clusters of repeated transcribed elements. In the equivalent human interval, there are also repeated elements that include the transcribed MAGE genes (Rogner et al. 1995) and three copies of the sequence DXS52 (Feil et al. 1990). The functional significance of these repeats is unknown, but similar clusters of repeats have been identified in several other regions of the $\mathrm{X}$ chromosome and many autosomes. These repeats have been proposed as, and in some cases, demonstrated to be sites for genomic rearrangements involving the genes in each region (Lupski et al. 1996). An additional $\mathrm{GABA}_{\mathrm{A}}$ receptor gene (GABRA3) has been mapped within Xq28 $\sim 300 \mathrm{~kb}$ proximal to the one reported here. Clustered GABA receptors have been identified elsewhere in the genome (e.g., the $\gamma 3, \beta 3$, and $\alpha 5$ subunits on 15q); however, divergence of sequences among family members makes intergenic recombination among the elements within a cluster unlikely.

Based on their expression patterns and/or homologies of the predicted amino acid sequences to known genes or gene families, several of the trapped exons and partial cDNAs represent good candidates for the Bpa and/or Str mutations. It is anticipated that the genes involved in these mutations would be expressed at or near the time when affected male embryos die, in the periimplantation period for $B p a$ and mid-gestation for Str. A more widespread timing and 

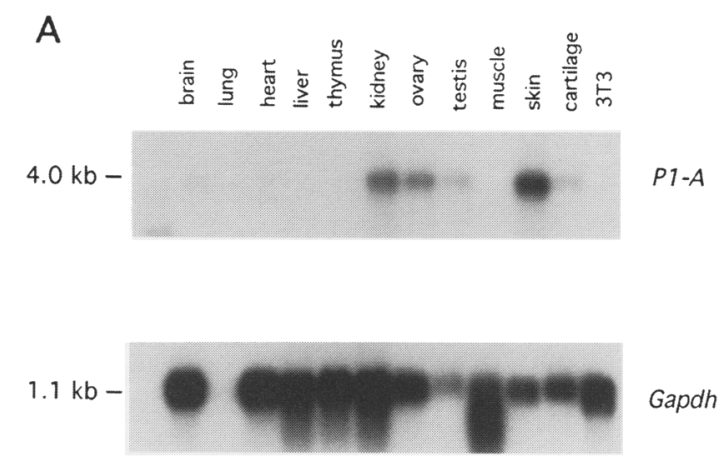

B
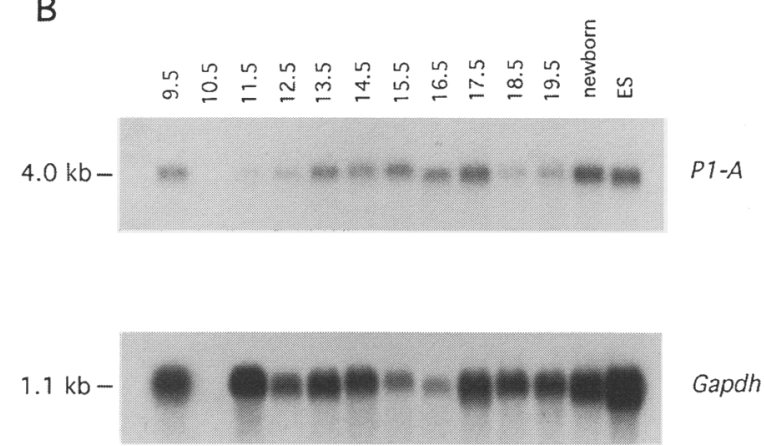

Figure 4 Northern blot hybridizations of $P 1-A$ to murine tissues $(A)$ and mid-gestation embryos and ES cells $(B)$. All tissues were from adult mice except for thymus (obtained from a 2-week-old animal) and skin and cartilage (obtained from newborn mice). 3T3 is RNA from the NIH 3T3 cell line, which resembles skin fibroblasts. Bands were visualized for $P 1-A$ after exposure for 7 days at $-80^{\circ} \mathrm{C}$ using two intensification screens. Exposure on the same blot with Gapdh was $6 \mathrm{hr}$. RNA in the lanes marked lung and 10.5-day embryo was degraded.

tissue distribution of expression could also be envisioned and would likely include skin fibroblasts and cartilage, at least for Bpa.P1-A is an excellent candidate for Bpa or Str because it maps to the critical region defined for both mutations, it is expressed in embryonic stem (ES) cells and in all embryonic stages tested, and it has its highest levels of expression in newborn skin. Although its sequence has no significant homology to known genes, a search for the presence of aminoacid motifs revealed that it probably contains a single LIM domain at its $3^{\prime}$ end. A human EST that appears to be the human ortholog of P1-A retains this domain. The first LIM domain protein was described in Caenorhabditis elegans in 1988, and several subtypes of this diverse group of proteins are now known (for review, see Sanchez-Garcia and Rabbitts 1994; Dawid et al.
1995). These include proteins that contain homeo domains in addition to two LIM domains and LIM-only proteins. The latter may contain as many as five or as few as a single LIM domain composed of two characteristic zinc fingers joined by a two-amino-acid spacer. Structural cytoskeletal proteins, such as zyxin, contain several LIM domains at their 3' end, whereas other LIMonly proteins, such as the humain oncogene rhombotin 1, appear to be involved in cellular differentiation and proliferation. It has been speculated that LIM domains function in protein-protein interactions and have diverse roles from transcription factors to cell adhesion proteins. For most LIM proteins, the factors with which they interact remain unknown. Based on the pattern of expression of $P 1-A$ and the presence of a perfect LIM domain at its $3^{\prime}$ end, we believe that this protein probably functions as a regulatory molecule during murine embryonic and early postnatal development. We are currently developing antibodies to the protein as well as isolating possible Drosophila homologs to better address the function of this novel transcript.

The $Z f p 92$ protein contains $\mathrm{KRAB} A$ and $\mathrm{B}$ boxes and 8-9 Krüppel-like zinc fingers, and is, therefore, likely to be a transcription factor. KRAB boxes are conserved domains present near the amino terminus of one-third of all Krüppeltype zinc finger proteins. Recent experimental data suggest that they can bind to DNA and function as transcriptional repressors (Margolin et al. 1994). Mutations in the $\mathrm{C}_{2} \mathrm{H}_{2}$ Krüppel-like proteins GLI3 and WT1 are associated with the developmental disorders Grieg cephalopolysyndactyly (Vortkamp et al. 1991) and familial Wilm's tumor/Denys-Drash syndrome (Pelletier et al. 1991), respectively, providing a precedent for the involvement of this class of proteins in human inherited diseases. Although $Z f p 92$ lies outside the Str critical region, it is an excellent candidate for the $B p a$ mutation.

Although P1-A and Zfp92 might seem to be the most likely candidates for the Bpa and/or Str mutations, we cannot absolutely exclude any of the partial cDNAs or exons described here. The original Bpa and Str alleles were X-irradiation induced. We have looked for genomic rearrangements in DNA from affected Bpa and Str females and from somatic cell hybrids that contain a single Bpa or Str-affected X chromosome using cosmids from our contig, trapped murine exons, and the partial murine and human cDNAs de- 


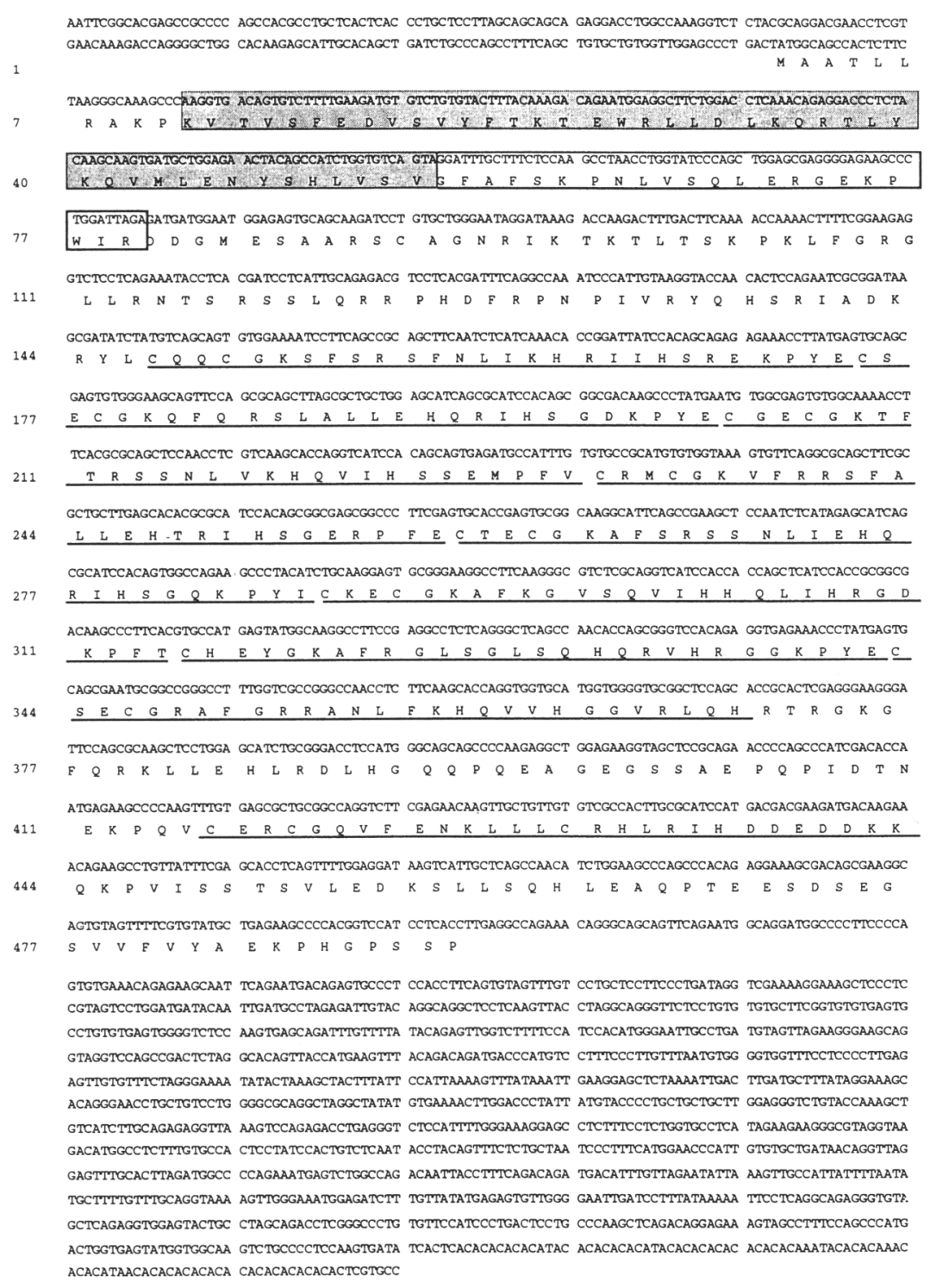

Figure 5 Complete nucleotide sequence and predicted amino acid sequence of Zfp92. Representation of the sequence is as in Fig. 3. The shaded and open boxes represent the KRAB $A$ and $B$ boxes, respectively. The nine zinc fingers are underscored. A good Kozak consensus sequence was present at the initiator methionine and an in-frame stop codon was present 41 bases 5 ' to the start site. An interrupted CA repeat was present at the end of the sequence, and no polyadenylation signal was noted. able to perform similar studies using exons $10-27$ or 10-41 from $Z f p 92$ because of their low levels of expression or with male Bpa embryos because of their death in the periimplantation period. Exclusion of $P 1-A$ and $Z f p 92$ as candidates for $B p a$ and $S t r$ will require sequencing of the genes or cDNAs from affected $X$ chromosomes. In addition, the isolation of longer cDNAs for other trapped exons, the isolation of more transcripts, and the isolation and sequencing of murine cDNAs corresponding to CALT and H105E3 may all be required to identify these mutations. Although this may seem to be a daunting task, we have already demonstrated that novel genes can be identified in the interval despite the growing number of sequenced human ESTs and large-scale gene identification efforts in Xq28 (Coy et al. 1994; Lee et al. 1995). We believe that the isolation of very low expression transcripts with limited tissue distributions may require the methodical search by a variety of methods for all of the genes in a region or the eventual sequencing of the entire human genome. scribed above. In comparison with control DNAs from the appropriate mouse strains, we have detected no abnormal or rearranged DNA fragments (data not shown). In addition, affected Str male embryos recovered at 9.5-11.5 days pc and genotyped using a PCR assay at DXMit1 (M. Levin and G. Herman, unpubl.) have demonstrated normal expression by RT-PCR of P1-A exons 6 and 7c, $33 \mathrm{a} 3$ and $33 \mathrm{a} 12$, and 16/135. We have been un-

\section{METHODS}

\section{Cosmid and PI Contig Assembly}

High-molecular-weight DNA prepared from the murine YACs B16S5, C73E6, B20S1, C131B2, D35D6, and from the human YAC CA02519 was partially digested with MboI (New England Biolabs) and subcloned into the Supercos vector (Stratagene) as recommended by the manufacturer. Cosmids containing murine or human inserts were selected by hybridization with total mouse or human ge- 
nomic DNA, respectively, as well as by a lack of hybridization with yeast genomic DNA. For the isolation of human cosmids from the gridded LLNL $\mathrm{X}$ chromosome cosmid library, individual YACs were excised from $0.8 \%$ Sea Plaque agarose (FMC) pulsed-field gels, radiolabeled using the random hexamer method (Feinberg and Vogelstein 1984), and hybridized to human cosmid filters as described (Chatterjee et al. 1994). Cosmid DNA was routinely prepared using an Autogen 740 (Integrated Separation Systems) or using a Qiagen Plasmid Midi-Kit. Three murine P1 clones in the vector pAd10-SacBII (Pierce et al. 1992) were obtained from Genome Systems by PCR screening with primers for the loci DXBay 18 and DXBay20, which detect the right ends of the YACs C73E6 and C131B2, respectively. Restriction enzyme digestions and Southern hybridizations were performed as described (Faust and Herman 1991; Chatterjee et al. 1994).

\section{Exon Trapping and CDNA Isolation}

Exon trapping was performed using individual cosmid or P1 clones and the vector PSPL 3 as recommended by Life Technologies. cDNA selection was performed with the human YAC CA02519 as reported (Pizzuti et al. 1993). Sixty selected cDNAs were subcloned into pBluescript (Stratagene), and the inserts isolated by PCR. Eighteen of the clones appeared unique and did not hybridize to repetitive human DNA, vector, or ribosomal sequences. A single clone (cDNA2) hybridized to the Xq28 specific somatic cell hybrid Q1Z and the YAC CA02519 and was analyzed in greater detail. The human cDNA H105E3 was identified using reciprocal probings of arrayed cosmids and cDNAs (Lee et al. 1995). To isolate longer transcripts for exons from the P1A clone, a 463-bp reverse transcriptase product was obtained from adult murine kidney mRNA by exon connection using forward (5'-CTTGGTGTTCTGAGGAAGAC) and reverse (5'-CAGTCCTGGCTTTGATTTG) primer sequences from exons $\mathrm{P} 1-\mathrm{A}-7 \mathrm{~g}$ and $\mathrm{P} 1-\mathrm{A}-7 \mathrm{C}$, respectively. Hybridization screening of an 8.5-day pc mouse embryo library obtained from Dr. B. Hogan (Vanderbilt University, Nashville, TN) or an adult mouse brain library (Clontech) with the 463-bp fragment did not produce any positive clones. A single clone was subsequently identified in an adult female B6CBA $F_{1}$ thymus cDNA library (Stratagene). To isolate the $Z f p 92$ cDNA, the 8.5-day embryo and adult brain cDNA libraries and Stratagene custom 129/SV 14.5-day embryo cDNA library obtained from Dr. A. Bradley (Baylor College of Medicine, Houston, TX) were screened by hybridization with exons $10-41$ and 10-27. These exons contain the highly conserved KRAB boxes, and the first six clones identified did not map to the $X$ chromosome. Rehybridization of the 14.5-day embryo filters with the exon 10-46, which is not conserved across species and had no known homologies, identified two identical clones that were also positive with the $10-41$ and 10-27 exons.

\section{Northern Hybridizations and RT-PCR Expression Studies}

For total RNA, mouse tissues or embryos obtained after timed matings were solubilized using RNAzol B (Tel-test), and mRNA was isolated using magnetic Oligo $\left(\mathrm{d}^{\mathrm{T}}\right)_{25}$ Dynabeads (Dynal). Approximately $1 \mu \mathrm{g}$ of mRNA was loaded per lane for Northerns, and electrophoresis was performed in 1\% agarose/MOPS/formaldehyde (Sambrook et al. 1989). RNA was transferred to SureBlot membranes (Oncor), and hybridizations were performed in $5 \times$ SSPE, $2 \times$ Denhardt's, $100 \mu \mathrm{g} / \mathrm{ml}$ of denatured herring sperm DNA, $50 \%$ formamide, and $2 \%$ SDS. Murine cDNA probes were labeled as above and $1 \times 10^{6}$ to $2 \times 10^{6} \mathrm{cpm} / \mathrm{ml}$ of hybridization buffer added per filter. Filters were rinsed in $2 \times$ SSC, $0.05 \%$ SDS at room temperature, and washed for $40 \mathrm{~min}$ at $50^{\circ} \mathrm{C}$ in $0.1 \times \mathrm{SSC}, 0.1 \%$ SDS before exposure under x-ray film for $6 \mathrm{hr}-7$ days. A murine Gapdh control cDNA probe was prepared as described (Nakao et al. 1994). For RT-PCR assays, 500-1000 ng of mRNA was treated with RQ1-RNase free DNase (Promega) in the presence of RNase inhibitor (Promega). Ten microliters of treated product was employed in a reverse transcriptase reaction that also contained $10 \mathrm{~mm}$ Tris, pH 9.0, $50 \mathrm{~mm} \mathrm{KCl}, 2.5 \mathrm{~mm}$ $\mathrm{MgCl}_{2}, 0.1 \%$ Triton X-100, 80 units RNase inhibitor, 400 ng random hexamer, and 200 units Superscript II RT (Life Technologies). Control reactions contained no enzyme and gave no product in subsequent PCR reactions. Product from the reverse transcriptase reaction $(0.2 \mu \mathrm{l})$ was used in a standard 35-40 cycle PCR amplification with AmpliTaq polymerase (Perkin-Elmer).

\section{DNA Sequencing and Sequence Analysis}

Single-stranded dideoxy DNA sequencing was performed for cloned, trapped exons and the GABRB4 cDNA with $\left[\alpha-{ }^{32} \mathrm{P}\right] \mathrm{dATP}$ (Dupont) using a Sequenase $2.0 \mathrm{kit}$ (USB). Automated fluorescent DNA sequencing of the cDNA clones H105E3, P1-A, and Zfp 92 was performed on an ABI 373A DNA sequencer. DNA sequences were routinely analyzed for DNA and protein homologies using the NCBI BLAST email server. Homologies were considered significant for $P(\mathrm{~N})>10^{-3}$. Sequence assembly for the cDNA clones was performed using the AutoAssembler Program (ABI).

\section{ACKNOWLEDGMENTS}

We thank Leif Bergsagel and Michael Kuehl for providing the $X I r 3 b$ cDNA, Juanita Gonzales for expert technical assistance, Jestina Mason and Jennifer L. Bailey for performing the automated sequencing of cDNAs, and Nelly Rivera for help in the preparation of the manuscript. We thank Bernhard Korn, Nina Heiss, and Annemarie Poustka for sharing data concerning their human Xq28 cDNAs before publication. The human chromosome-specific gene library LLOXNC01 used in this work was constructed at the Biomedical Sciences Division, Lawrence Livermore National Laboratory, Livermore, California 94550 under the auspices of the National Laboratory Gene Library Project sponsored by the U.S. Department of Energy. M.L.L. was supported in part by a National Institutes of Health (NIH) postdoctoral fellowship (5 F32 AR08294). This work was also supported by NIH grant R01 NS34953 (G.E.H.), by the Baylor Child Health Research and Mental Retardation Research Centers, and by the Clayton Foundation for Research (C.C.L.). The sequence data described in this paper have been submitted to the GenBank data library under 


\section{LEVIN ET AL.}

accession nos. U46687, U47104-U47105, U47334, and U52227-U52239.

The publication costs of this article were defrayed in part by payment of page charges. This article must therefore be hereby marked "advertisement" in accordance with 18 USC section 1734 solely to indicate this fact.

\section{REFERENCES}

Angel, T., C. Faust, J. Gonzales, S. Kenwrick, R.A. Lewis, and G.E. Herman. 1993. Genetic mapping of the $\mathrm{X}$-linked dominant mutations striated (Str) and bare patches $(B p a)$ to a $600-\mathrm{kb}$ region of the mouse $\mathrm{X}$ Chromosome: Implications for mapping human disorders in Xq28. Mamm. Genome 4: 171-176.

Aubry, M., C. Marineau, F.R. Zhang, L. Zahed, D. Figlewics, O. Delattre, G. Thomas, P.J. de Jong, J.-P. Julien, and G.A. Rouleau. 1992. Cloning of six new genes with zinc finger motifs mapping to short and long arms of human acrocentric chromosome 22 (p and q11.2). Genomics 13: 641-648.

Bellefroid, E.J., P.J. Lecocq, A. Benhida, D.A. Pondelet, A. Belayew, and J.A. Martial. 1989. The human genome contains hundreds of genes coding for finger proteins of the Kruppel type. DNA 8: 377-387.

Bergsagel, P.L., C.R. Timblin, C.A. Kozak, and W.M. Kuehl. 1994. Sequence and expression of murine cDNAs encoding XIr3a and Xlr3b, defining a new X-linked lymphocyte-regulated XIr gene subfamily. Gene 150: $345-350$.

Chatterjee, A., C.J. Faust, L. Molinari-Storey, P. Kiochis, A. Poustka, and G.E. Herman. 1994. A 2.3 Mb yeast artificial chromosome contig spanning from Gabra3 to G6pd on the mouse X chromosome. Genomics 21: 49-57.

Chatterjee, A., T. Tanaka, J.E. Parrish, and G.E. Herman. 1995. Refined mapping of caltractin in human Xq28 and in the homologous region of the mouse $X$ chromosome places the gene within the bare patches $(B p a)$ and striated (Str) critical regions. Mamm. Genome 6: 802-804.

Coy, J.F., P. Kioschis, Z. Sedlacek, and A. Poustka. 1994. Identification of tissue-specific expressed sequences in human band Xq28 with complex pig cDNA probes. Mamm. Genome 5: 131-137.

Davisson, M.T. 1987. Review: X-linked genetic homologies between mouse and man. Genomics 1: 213-227.

Dawid, I.B., R. Toyama, and M. Taira. 1995. LIM domain proteins. C.R. Acad. Ser. III Sci vie 318: 295-306.

de Gouyon, B., A. Chatterjee, A. Monaco, N. Quaderi, S.D.M. Brown, and G.E. Herman. 1996. Comparative mapping on the mouse $\mathrm{X}$ chromosome defines a myotubular myopathy region. Mamm. Genome (in press).

Faust, C.J. and G.E. Herman. 1991. Physical mapping of the loci Gabra3, DXPas8, CamL1, and Rsvp in a region of the mouse $\mathrm{X}$ chromosome homologous to human $\mathrm{Xq} 28$. Genomics 11: 154-164.

Faust, C.J., B. Levinson, J. Gitschier, and G.E. Herman. 1992. Extension of the physical map in the region of the mouse $\mathrm{X}$ chromosome homologous to human $\mathrm{Xq} 28$ and identification of an exception to conserved linkage. Genomics 13: 1289-1295.

Feil, R., G. Palmieri, M. d'Urso, R. Heilig, I. Oberle, and J.L. Mandel. 1990. Physical and genetic mapping of polymorphic loci in Xq28 (DXS15, DXS52, and DXS134): Analysis of a cosmid clone and a yeast artificial chromosome. Am. I. Hum. Genet. 46: 720-728.

Feinberg, A.P. and B. Vogelstein. 1984. A technique for radiolabeling DNA restriction endonuclease fragments to high specific activity: Addendum. Anal. Biochem. 137: $266-277$.

Happle, R. 1979. X-linked dominant chondrodysplasia punctata. Hum. Genet. 53: 65-73.

1987. The lines of Blaschko: A developmental pattern visualizing functional X-chromosome mosaicism. Curr. Probl. Dermatol. 17: 5-18.

Happle, R., R.J.S. Phillips, A. Roessner, and G. Junemann. 1983. Homologous genes for X-linked chondrodysplasia punctata in man and mouse. Hum. Genet. 63: 24-27.

Herman, G.E., C.J. Faust, M.G. Darlison, and E.A. Barnard. 1991a. Genetic mapping of the mouse X chromosome in the region homologous to human Xq27-Xq28. Genomics 9: 670-677.

Herman, G.E., M. Berry, E. Munro, I.W. Craig, and E.R. Levy. 1991b. The construction of human somatic cell hybrids containing portions of the mouse $\mathrm{X}$ chromosome and their use to generate DNA probes via interspersed repetitive sequence polymerase chain reaction. Genomics 10: $961-970$.

Herman, G.E., H.J. Blair, Y. Boyd, S.D.M. Brown, B. de Gouyon, A. Haynes, and N. Quaderi. 1996. The mouse X chromosome. Mamm. Genome (in press).

Kozak, M. 1989. The scanning model for translation: An update. J. Cell Biol. 108: 229-241.

Landy, S.J. and D. Donnai. 1993. Incontinentia pigmenti (Bloch-Sulzberger syndrome). J. Med. Genet. 30: 53-59.

Lee, C.C.L., A. Yazdani, M. Wehnert, Z. Zhao, E.A. Lindsay, J. Bailey, M.I. Coolbaugh, L. Couch, M. Xiong, A.C. Chinault, A. Baldini, and C.T. Caskey. 1995. Isolation of chromosome-specific genes by reciprocal probing of arrayed cDNA and cosmid libraries. Hum. Mol. Genet. 4: 1373-1380.

Levinson, B., S. Kenwrick, D. Lakich, G. Hammonds, and J. Gitschier. 1990. A transcribed gene in an intron of the human factor VIII gene. Genomics 7: 1-11. 


\section{A IRANSCRIPIION MAP OF THE BPA/STR REGION AND Xo28}

Lupski, J.R., J.R. Roth, and G.M. Weinstock. 1996. Chromosomal duplications in bacteria, fruit flies, and humans. Am. J. Hum. Genet. 58: 21-27.

Macdonald, R.L. and R.W. Olsen. 1994. GABA A receptor channels. Annu. Rev. Neurosci. 17: 569-602.

Margolin, J.F., J.R. Friedman, W.K.-H. Meyer, H. Vissing, H.-J. Thiesen, and F.J. Rauscher III. 1994. Kruppel-associated boxes are potent transcriptional repression domains. Proc. Natl. Acad. Sci. 91: 4509-4513.

Nakao, M., J.S. Sutcliffe, B. Durtschi, A. Mutirangura, D.H. Ledbetter, and A.L. Beaudet. 1994. Imprinting analysis of three genes in the Prader-Willi/Angelman region: SNRPN, E6-associated protein, and PAR-2 (D15S225E). Hum. Mol. Genet. 3: 309-315.

Nelson, D.L., S.A. Ledbetter, L. Corbo, M.F. Victoria, R. Ramirez-Solis, T. Webster, D.H. Ledbetter, and C.T. Caskey. 1989. Alu polymerase chain reaction: A method for rapid isolation of human-specific sequences from complex DNA sources. Proc. Natl. Acad. Sci. 86: $6686-6690$.

Nelson, D.L., A. Ballabio, F. Cremers, A.P. Monaco, and D. Schlessinger. 1996. Report of the Sixth International Workshop on X Chromosome Mapping 1995. Cytogenet. Cell Genet. (in press).

Palmieri, G., G. Romano, A. Ciccodicola, A. Casamassimi, C. Campanile, T. Esposito, V. Cappa, A. Lania, S. Johnson, R. Reinbold, A. Poustka, D. Schlessinger, and M. D'Urso. 1994. YAC contig organization and $\mathrm{CpG}$ island analysis in Xq28. Genomics 24: $149-158$.

Pelletier, J., W. Bruening, C.E. Kashtan, S.M. Mauer, J.C. Manivel, J.E. Striegel, D.C. Houghton, C. Junien, R. Habib, L. Fouser, R.N. Fine, B.L. Silverman, D.A. Haber, and D. Housman. 1991. Germline mutations in the Wilms' tumor suppressor gene are associated with abnormal urogenital development in Denys-Drash syndrome. Cell 67: 437-447.

Phillips, R.J.S. 1963. Striated, a new sex-linked gene in the house mouse. Genet. Res. 4: 151-153.

Phillips, R.J.S., S.G. Hawker, and H.J. Moseley. 1973. Bare-patches, a new sex-linked gene in the mouse, associated with a high production of $X O$ females. I. A preliminary report of breeding experiments. Genet. Res. 22: 91-99.

Pierce, J.C., N. Sternberg, and B. Sauer. 1992. A mouse genomic library in the bacteriophage P1 cloning system: Organization and characterization. Mamm. Genome 3: $550-558$.

Pizzuti, A., M. Gennarelli, G. Novelli, A. Colosimo, S. Lo Cicero, C.T. Caskey, and B. Dallapiccola. 1993. Human elongation factor EF-b: Cloning and characterization of the EFb5a gene and assignment of EF-1b isoforms to chromosomes 2,5,15 and X. Biochem. Biophys. Res. Commun. 197: 154-162.

Rogner, U.C., P. Kioschis, K. Wilke, W. Gong, E. Pick, A. Dietrich, U. Zechner, H. Hameister, A. Pragliola, G.E. Herman, J.R. Yates, H. Lehrach, and A. Poustka. 1994. A YAC clone map spanning the human chromosomal band Xq28. Hum. Mol. Genet. 3: 2137-2146.

Rogner, U.C., K. Wilke, E. Steck, B. Korn, and A. Poustka. 1995. The melanoma antigen gene (MAGE) family is clustered in the chromosomal band Xq28. Genomics 29: $725-731$.

Sambrook, J., E.F. Fritsch, and T. Maniatis. 1989. Molecular cloning: A laboratory manual. Cold Spring Harbor Laboratory Press, Cold Spring Harbor, NY.

Sanchez-Garcia, I. and T.H. Rabbitts. 1994. The LIM domain: A new structural motif found in zinc-finger-like proteins. Trends Genet. 10: 315-320.

Sefiani, A., L. Abel, S. Heuertz, D. Sinnett, L. Lavergne, D. Labuda, and M.C. Hors-Cayla. 1989. The gene for incontinentia pigmenti is assigned to Xq28. Genomics 4: $427-429$.

Smahi, A., C. Hyden-Granskog, B. Peterlin, P. Vabres, S. Heuertz, M.C. Fulchignoni-Lataud, N. Dahl, P. Labrune, B. Le Marec, C. Piussan, A. Taieb, H. von Koskull, and M.C. Hors-Cayla. 1994. The gene for the familial form of incontinentia pigmenti (IP2) maps to the distal part of Xq28. Hum. Mol. Genet. 3: 273-278.

Traupe, H., D. Muller, D. Atherton, D.C. Kalter, F.P.M. Cremers, B.A. van Oost, and H.-H. Ropers. 1992. Exclusion mapping of the X-linked dominant chondrodysplasia punctata/ichthyosis/cataract/short stature (Happle) syndrome: Possible involvement of an unstable pre-mutation. Hum. Genet. 89: 659-665.

Vortkamp, A., M. Gessler, and K.-H. Grzeschik. 1991. GLI3 zinc finger gene interrruped by translocations in Greig syndrome families. Nature 352: 539-540.

Wapenaar, M.C., M.V. Schiaffino, M.T. Bassi, L. Schaefer, A.C. Chinault, H.Y. Zoghbi, and A. Ballabio. 1994. A YAC-based binning strategy facilitating the rapid assembly of cosmid contigs: $1.6 \mathrm{Mb}$ of overlapping cosmids in Xp22. Hum. Mol. Genet. 3: 155-1161.

Wettke-Schafer, R. and G. Kantner. 1983. X-linked dominant inherited diseases with lethality in hemizygous males. Hum. Genet. 64: 1-23.

Worley, K.C., B.A. Wiese, and R.F. Smith. 1995. BEAUTY: An enhanced BLAST-based search tool that integrates multiple biological information resources into sequence similarity search results. Genome Res. 5: 173-184.

Received February 5, 1996; accepted in revised form April 17, 1996. 


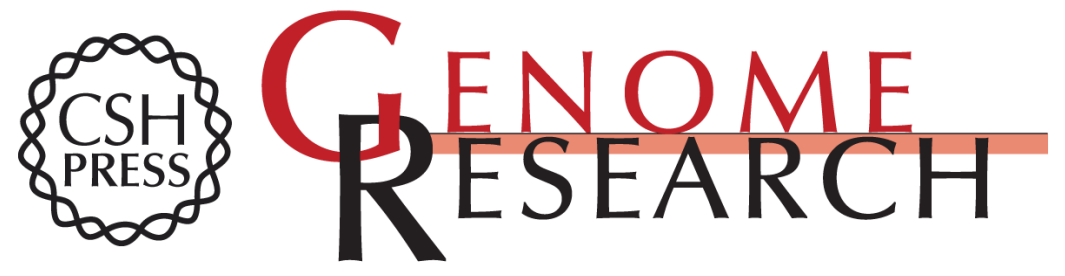

\section{A comparative transcription map of the murine bare patches (Bpa) and striated (Str) critical regions and human Xq28.}

M L Levin, A Chatterjee, A Pragliola, et al.

Genome Res. 1996 6: 465-477

Access the most recent version at doi:10.1101/gr.6.6.465

References This article cites 43 articles, 5 of which can be accessed free at:

http://genome.cshlp.org/content/6/6/465.full.html\#ref-list-1

\section{License}

Email Alerting Receive free email alerts when new articles cite this article - sign up in the box at the Service top right corner of the article or click here.

\section{Affordable, Accurate Sequencing.}

To subscribe to Genome Research go to:

https://genome.cshlp.org/subscriptions 